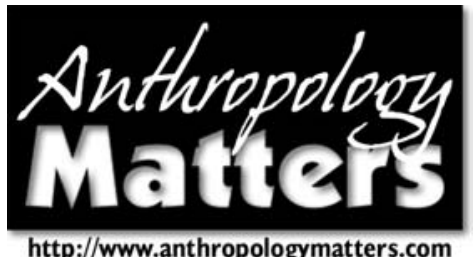

Anthropology Matters Journal 2006, Vol 8 (1)

\title{
In quest of Eastern Europe: troubling encounters in the post- Cold War field
}

By Eleni Sideri (SOAS)

This paper examines various transformations regarding the categories of 'us' and 'them' that occurred during my year of fieldwork in Georgia (2003-2004). My research questions concerning the formation of a 'Greek diaspora' in Georgia through family memories and historiographical accounts led me to 'paradoxical' encounters, which seemed to challenge my perceptions of selfhood as well as my ideas about the political, historical and geographical topographies of Greece and Georgia. These troubling encounters seemed to drive me to a re-conceptualisation of both 'East' and 'West', not only as spatial and temporal/historical entities, but also as mutually constructed ideologies during the Cold War and post-Cold War period.

\section{New Europe, old Europe and the oldest Europe}

"Georgia is neither "old Europe" nor "new Europe". Georgia is one of the oldest parts of Europe,' Mikhail Saakashvili, the new president of Georgia, underlined in a speech following the peaceful revolution that led to a change of regime in November 2003 (Saakashvili 2004:3). The problem of belonging is not new for Georgia. The geographical position of the country - in the south of the Caucasian range and between the Caspian Sea and the Black Sea- has made finding solutions to this problem a matter of political and cultural survival since the fourth century AD, when the Georgians converted to Orthodox Christianity. Up to the present day, religion is perceived as explicit proof of the country's participation in European history and culture.

However, decisions about political alignment have not always been left to the Georgians. The arrival of the Red Army in Tbilisi in 1921, for example, signalled the forced incorporation of the Georgian Republic, after a brief independence (1918-1921) following 117 years of Russian imperial presence, into the emerging Soviet Union. If the violent intersection of Georgian and Russian histories today classifies the country as one of the new independent republics that emerged after the fall of the Soviet Union, this is not how the country's President perceives his country's geopolitical position and future. Geography, history and politics were always in turbulent negotiation, as this brief depiction of Georgian history shows. But political perceptions of space are far from a Georgian innovation. Anthropology and other disciplines have studied the conceptualisation of space in different social contexts and histories, and depicted how the latter is socially constructed. 
For Heidegger (2003), living is primarily an act of dwelling that embeds all human experience in time and history. Being must be implaced and therefore any thinking about our 'existence' demands the use of spatial categories rather than simply abstract forms. How-we might ask-are these categories constructed? For Lefebvre, 'space is a product' (1991:35) of practice, whereby perceptions of space are constructed through a combination of (i) social experience and practice (pratique sociale), (ii) collective representations at a political, scientific and economic level (représentation de l'espace) and (iii) symbolic expressions and codes (espace de représentation). Moreover, if perceptions of space are in some ways reflections of socio-economic and political practice, then its very representation as homogenous is generated from the dialectical relation between practice, conception and imagination (Harvey 1994:218-219, Lefebvre 1991:43).

Within anthropology, 'space' is frequently constructed through the delineation of disciplinary regions, which Fardon (1990) argues creates certain traditions and also shapes presuppositions, interests and theoretical orientations. However, when Fardon made this argument, 'Eastern Europe' was itself only of relatively minor interest to mainstream anthropology - an oversight that ignores the fact that since the emergence of Eastern Europe and the Soviet Union as a political space after World War II, they have constituted a social and political Other that has acted as an important oppositional pole to 'the West'. This role as the West's Other became a key factor in the shaping of assumptions about 'ourselves' since the beginning of the Cold War. However, after the fall of the Berlin Wall in 1989 and the dismemberment of the Soviet Union, when the initial shock or excitement had died down, the discipline borrowed these terms to express a new field of interest: namely the anthropology of 'Eastern Europe and the former Soviet Union'.

In broad terms, 'Eastern Europe' used to refer to the Soviet 'satellite' states, which, despite their formal independence from the Soviet Union, were all, to varying degrees, under its influence, both political and economic. Another factor that distinguished the states of Eastern Europe from the former Soviet republics, like the republic of Georgia, was the later incorporation of the former into the Soviet zone of political influence. This did not happen until the dividing lines drawn by the victorious sides of World War II (in the Yalta Agreement of 1945) created new ideological and physical 'borders' on the European continent. Until that point, 'Eastern Europe' had been able to follow western European trends: imperial colonialism and antagonism, emerging nationalism, and statehood.

Many of the Soviet republics, on the other hand, only became nations under the pressure of Soviet nationality policy. The latter was conceived by the Bolshevik leadership as a project aimed at the development of national cultures which could be equally respected and integrated in the Soviet federation, leaving behind the discontentment created by the Russian colonialism of the nineteenth century. In this way, it was believed that the ideas of the Russian Revolution of 1917, followed by the creation of the Soviet Union, could be accepted without contestation by the various peoples living within its borders. However, as the Georgian case illustrates, not all the Soviet republics went through ethno-genesis as a result of Soviet planning. Georgia, for instance, experienced a vibrant national movement in the nineteenth century, when it still formed part of the Russian Empire. 
As a result, it cannot be taken for granted that there is a distinction between the more developed national consciousness of the countries of Eastern Europe as compared to those of the former Soviet Union. Nonetheless, the degree of economic control of Moscow over the Soviet national republics remains an important distinguishing feature between the two areas. However, the creation of a common economic space, a common market (COMECON) between the Soviet Union and its political allies in Eastern Europe caused the development of specific economic and political relations between each of these countries and the Kremlin, which should not be underestimated when ethnographic fields are delineated (Wallace 1999).

Another reason why they are both often discussed as one field, especially in terms of ethnographic considerations, is that after the initial shock that followed the fall of the Soviet Union, such a new field did indeed seem to arise (Wolfe 2000). However, the designation of a widely applied and supposedly unproblematic name for this field, as I discussed above, raised serious doubts about its homogeneity. These problems made it obvious that the anthropology of Eastern Europe referred to a space that was constructed through a period of extreme polarisation, ideological prejudice, and minimum - or zerocommunication between the Cold War rivals. This 'space' covered countries with very distinct histories, stretching much further back than their gradual attachment to the Soviet sphere of influence or development within the Union itself, as the Georgian case shows. Most importantly, the emergence of the new independent republics viewed their postindependence future in distinct ways.

The near-terra incognita behind the former Iron Curtain became a Promised Land that 'created new opportunities both for established scholars and for a new generation of fieldworkers', as Hann, Humphrey and Verdery (2002:2) argued in their introduction regarding the construction of 'post-socialist' space and anthropology. The new generation and established scholars alike now had the opportunity to re-visit the field in a more relaxed manner, and they frequently shifted their attention from totalitarianism to more everyday themes (Silverman 2000). At the same time, questions were raised about methodologies and dilemmas specific to this new space. As Dudwick and de Soto put it in one of the volumes published to discuss the specific problems of doing fieldwork in the post-socialist states, their work 'emerged out of a feeling, shared by all the authors, that there was something peculiarly postsocialist about the inevitable complexity of fieldwork relationships we were experiencing' (2000:6-7, my emphasis). While I found their comments stimulating when I was preparing for my fieldwork in Georgia, upon returning and trying to make sense of my experience I cannot help wondering what makes my experience 'peculiarly post-socialist' and why I am eligible to identify myself as a 'postsocialist fieldworker'.

In this paper, I argue that the existence of an anthropology of Eastern Europe presupposes its counterpart, Western Europe (Verdery 1996, Hann, Humphrey \& Verdery 2002: 1-29), in the sense that their construction as ideological spheres is interwoven and mutually dependent. More than a decade after the fall of the Soviet Union, I take this to be a sine qua non. I want to scrutinise why exploration of what post-socialism is and what its legacy might be or indeed whether it exists at all, has often failed to range more widely, frequently limiting itself to bringing out only the 'past' interdependence. In other words, this paper indicates that examination of the post-socialist field must not overlook the Cold 
War legacy of political representations of the 'post-socialist Self and the Other', and how they are both formulated within the political economy that emerged as 'post-Cold War reality'. Furthermore, I argue that this discussion should not see the Cold War simply as 'the past'. We must take one step further, examining what came next: that which is typically referred to as 'globalisation'. We should try to comprehend how the latter emerged in the aftermath of those political changes and how the old divisions are carried forward, if they are. First, though, I focus on the perceptions that moulded my own ideas, delineating the framework that shaped my knowledge about Georgia. I then depict reactions to my presence in the field, how I was framed and how people I met in Georgia construct their entry into the 'free world'.

\section{East goes West}

My first encounter with the former Iron Curtain was in fact in Greece, when Eastern Europe 'came West'. In terms of geography, this movement makes little sense if the locus of reference is Greece: Eastern Europe for Greece is in fact north or northwest Europe. However, it makes perfect sense if we are talking about Georgia, which is situated eastwards of Greece. However, the migration from the countries of the former Soviet Union to Greece had particular connotations for one of the groups that had migrated.

I did not know them at first. How could I? I was eighteen years old and none of my school textbooks referred to them. Their history was not part of us, of 'our' history. In 1991 I registered at Aristotle University of Thessaloniki. A long, rectangular square, which used to be part of a Byzantine palace, is located between the Humanities building and the shops. There I met them for the first time. They had laid some blankets on the white square tiles and placed upon them anything that could be sold: linen, clothes, cutlery, samovars, old books, cigarettes, bottles of vodka and outdated photographic equipment. I bought my first camera, a 'Laica', from them.

'The Rossopontioi ${ }^{l}$ hold their bazaar here every Wednesday,' I heard someone saying. I remember that the Greek government was under heavy pressure to save the 'brother Greeks' living in the former Soviet Union, first in Nagorno-Karabakh (Armenia/Azerbaidzhan), then in Fergana (Uzbekistan), and finally in Abkhazia (former Autonomous Region in the western part of the former Soviet Republic of Georgia). I even remember the newspaper headlines when the humanitarian expedition 'Golden Fleece' was organised to 'bring back' all the Greeks from Sukhum(i) (Abkhazia): 'The Argonauts' return'. After a while, mistrust arose about the flea markets: where do they

\footnotetext{
${ }^{1}$ The term was used to designate the group of migrants that arrived in Greece from various areas of the former Soviet Union in the 1990s and who claimed their origin to be in 'Pontos' (the Black Sea coast of Turkey), a region where many Greek-speaking communities used to live in the nineteenth century. The defeat of the Greek army in Asia Minor, by the Turkish army of Kemal Attaturk in 1922, led these communities to exile. Most of these people came to Greece as refugees in that year and became known as Pontic-Greeks. Others took refuge in South Caucasus (mainly Georgia and Armenia). The usage of the terms 'Rossopontioi' in the 1990s underlined the common origin of these two groups, but it also stressed their differences, namely in their Russian/Soviet experience. The term was soon used pejoratively to question the migrants' less 'authentic' Greekness.
} 
get all these things? It can't be their property. They are smuggling! What kind of Greeks are they? They speak only Russian.

The migration from Eastern Europe and the former Soviet Union caused reactions of brotherly solidarity in Greece, since the major issue was the 'return' of the Greek population living there. The question of who they were and why they found themselves there is an issue that goes beyond the scope of this paper. I will only say here that there were 100,000 Greeks in Georgia according to the last Soviet census (in 1989). The majority were descendants of migrants from the Ottoman Empire, mainly from the Black Sea coast, known in Greece as Pontos, who had never been to Greece. Their nineteenthcentury migrations reached a peak in 1922 with the end of the Greek-Turkish war, in which Greece was defeated (Hassiotis 1997).

This defeat is covered in a veil of silence in the life of the Greek communities in the Soviet Union, after the pre-World War II dictatorship in Greece and the later Cold War divisions placed the country in the West. However, this was not the only reason for the silence that I underlined in my fieldnotes. The Yalta Conference in 1945 sparked a civil war between the right and the left in Greece (1945-49), which was already ravaged by World War II. The end of this war and the defeat of the 'Democratic [communist] Army' forced many of its former fighters into exile. They were dispersed to various countries behind the Iron Curtain, from Czechoslovakia to Soviet Uzbekistan. The right wing governments in power in Greece did not allow much, at least official, remembering of this part of history. As the excerpt from my diary shows, the newspapers of that period stressed the continuity with ancient history or rather mythology (the Argonauts and the Golden Fleece), while modern political traumas remained behind a wall of silence. Inclusion in the Greek nation through reference to ancient Greek history is not surprising, if we consider how modern Greece was constructed as a topos of western imagination and the origin of the 'European spirit and civilisation' (Herzfeld 1987).

The years of political and social differences experienced by 'Greeks' living in the two worlds, Eastern and Western Europe, were somehow overlooked through the metaphysics of blood and history, which in this case differs little from myth. However, differences in language and material culture soon emerged. For example, as my diary entry referring to that first encounter shows, what impressed me most about their material culture, what was most different and thus 'exotic', was their samovars, the Laica cameras, the vodka. Rumours soon appeared that such goods had been smuggled in. Mistrust soon arose, in parallel with a climate of xenophobia, reinforced by the media, which called for protection from the Russian mafia. Here, however, I first want to underline the impact of history as continuity or rupture on the construction of the ideas that mediated my encounter with 'them'. Second, I wish to investigate the impact of recent economic and political conditions, which encouraged migration to Greece and the rising xenophobic discourse.

When I arrived in Georgia for the first time, what struck me most was a sense of déjà $v u$. It was not only the ecology, cuisine and forms of sociality, which might be comprehended within the common framework of Orthodox Christianity, but also the anxiety about the political and cultural belonging of Georgia and the quest for powerful alliances. It is no accident that Dudwick and de Soto's volume (2000) concludes with a contribution by Herzfeld, one of the best-known anthropologists of Greece, who tried to 
draw parallels between his experience in this country and the new post-socialist 'field'. It is the position of Greece 'at the margins' of Europe, its ambivalent straddling of traditions drawn from both 'East' and 'West', that made his experience relevant to comprehending the dilemmas arising from the 'new frontiers' of Europe.

When I found myself in Georgia, I started to realise how this Greek ambivalence was interpreted there. On one occasion, I was walking with a friend in the centre of Tbilisi, the capital. Outside a music shop, I told him that I would like to go inside to ask for a particular CD that I liked. It was by a Georgian group that made use of traditional sounds fused with a more pop rhythm. My friend laughed. 'It's no surprise that you like them,' he told me in a disapproving tone. 'They sound very oriental and you like that in Greece. This oriental sound is more in your tradition than in ours.' According to my Georgian friend, I was a more oriental or eastern subject than he was. Judging from his tone of voice, he was less than thrilled about that. His new President, after all, defined Georgia as 'one of the oldest parts of Europe'.

I soon realised I was more than 'oriental'. During a discussion with another Georgian friend working in the field of international relations for a local NGO in Tbilisi, I expressed reservations about Georgia's no-holds-barred rapprochement with and expectations of the USA. He told me: 'I know why you are saying this. It is because you Greeks, because of your past, ${ }^{2}$ are too leftist.' This was the second serious blow to my 'western' persona. I was both too eastern and too left-wing, which placed a question mark over who the Eastern European was. It was, again, the political agenda of present day Georgia and the perception of who Georgians are or should be or how the West is, that underlay these reactions.

By conceptualising the idea of 'West' as homogenous and equating it, fundamentally, with the USA, this Georgian man assessed my ideas and reactions in our conversation, placing me and consequently my country, on 'the left' and in the 'Orient'. In this sense, it seems that in post-Soviet Georgia divisions are still emerging in order to frame people's attitudes and perceptions about past and present. These divisions might not repeat the West/East polar duality of the past, but they still seem to give prominence to the first pole. My categorisation as 'leftist' because of my 'Greek past', as this man argued, illustrated that the fall of the Soviet Union was followed by internalisation of a certain image of the West. The latter seems to be widely identified with the USA, which is in fact the biggest international donor in Georgia, and a major donor for this man's NGO. Positioning me in that context (East/left), this Georgian man constructed his position in the antipode, the idealised 'West'.

However, taking positions is contextual and temporal. As I argued in the beginning of this paper, the conceptualisation of space can always be an outcome of ideological stances. The end of the Cold War with its well-established division between West and East had made these divisions more 'flexible' rather than eradicated them. That is why this man's perceptions regarding the reasons for my reaction to his ideas about USA policies in Georgia placed me on 'the left', a less convoluted category within the

\footnotetext{
${ }^{2}$ As he explained to me later, he was here referring to the Greek Civil War (1945-1949) between the Greek Communists and the conservative forces, which were supported by Greece's western allies. He also meant the military junta (1967-1974), which was widely perceived to be supported by the USA.
} 
Georgian political debates - especially after the fall of the Soviet Union-than any specific reference to communism or socialism. His interpretation, as he highlighted, was supported by the 'Greek past'.

It was the ambivalent position of Greece, in terms of its European and western identity, that made this man use the category 'leftist'. However, it was also this ambivalence that often made my Georgian interlocutors confess to me that I could understand them better. An inability to identify Greece strictly with their representation of what Europe is, enabled them to position themselves within a less rigid framework-defined by the bifurcation of West/East and within which they could feel their 'Eastern' past as a disadvantage, something they should be freed from. Difficulties regarding my positioning within the two poles made evident the ambiguities of their own position and ultimately, the shifting nature of the West/East dipole itself. As a result, they seemed willing to reassess the experiences that we both had, (they and myself), during the Cold War, and even to become critical of the 'regimes of truth' that were constructed during those years and their effects, as the following vignette illustrates.

Dela is in her early 30s like me. I had known her from Greece where she used to work as a shop assistant. Dela returned to Georgia after some time and got married there. We were discussing her life in Greece when she told me, 'You know, it's funny but I think that while we went through heavy propaganda, you didn't know anything about us either'. 'Why do you say that?' 'When I was at school they used to show us films about the poor people living in the USA so that we could be proud that we didn't have any unemployment or homeless people going around begging. But we know that it was all lies. It was propaganda. Nobody had faith in the system. But when I went to Greece and I had to find a flat I got a shock.' 'Why, what happened?' 'The landlord was showing me around. When we went into the kitchen, he opened the fridge and told me very seriously that I should keep the fridge well closed because we put the food there. He thought I hadn't seen a fridge before! Who, us? He said that he had thought that we were starving in the Soviet Union. I couldn't believe it. That's why I am telling you. You had propaganda too. You didn't know anything about us.'

In Dela's narrative a 'we' and 'you' relation is depicted. However, in one sense, her understanding of both is far from contradictory. Dela concludes that both we/you are victims of propaganda and ignorance. This led to embarrassing encounters. Dela's 'we' lived in a country encumbered with 'heavy propaganda', but as she admits they still 'knew' that the system was lying. When I asked her how, she gave me a list of strategies for finding the 'truth' about the West: artists and athletes visiting the West, intellectuals attending conferences, western films or products finding their way into the formal and informal markets of Georgia. Her idea about the 'West' was a representation formed by the media, restricted consumerism and the intelligentsia.

When she travelled to Greece, she realised that western impressions of Soviet life were quite different. Dela, child of a mixed marriage and an urban family who had been through higher education, met a landlord who tried to teach her how to use a fridge. He constructed Dela as a poor, almost uncivilised person, deprived of everything. This was a revealing moment for Dela, who realised that despite her image of the West, propaganda was also part of 'Free Europe'. Yet the landlord based his assumption not only on the past but also on the present: the fact that Dela came to Greece as migrant, while Greece was 
turning into a host country with an attractive economy. In the New World Order, where the divisions into East and West supposedly made no sense, new orders might still emerge, rewriting old and new divisions under new or not so new labels.

\section{Beyond the divisions}

In this paper, I have illustrated the kinds and layers of presuppositions, based on cultural or political orders, that exist in both Greece and Georgia, and which mediated my fieldwork. As I stated in the introduction, it is surprising that no 'post-Cold War' anthropology emerged after the fall of the Soviet Union (Hann, Humphrey \& Verdery 2002: 1-29). In other words, researchers seem to have neglected the more systematic examination of the continuities and discontinuities between the Cold War and what came after, both in terms of economic structures and socio-political experience and representation. I have here brought out how, for both West and East, transitions to the post-Cold War Europe brimmed over with new misunderstandings and embarrassing encounters. These stem from the past, but also from the present and the power relations evolving today, such as dependence on funding, or migration from the former Soviet Union to wealthier countries. Drawing attention to the ideologies involved in these 'awkward' moments, we seem to be obliged to delve into the constructions of our epistemologies and ethnographic traditions. As Herzfeld argues, 'the aim of situating ethnographic practice within the complex geopolitical dynamics of which it inevitably partakes' (2000:234) may mean stepping beyond political and geographical divisions, but also beyond the boundaries within the anthropological discipline itself in order to challenge them.

\section{References}

Department of Statistics of Georgia Population Census. 1989. Available at http://georgia-gateway.org (accessed on 12.03.2002).

Dudwick, N. and H.G. de Soto. 2000. Introduction. In Fieldwork Dilemmas; Anthropologists in Postsocialist States (eds) N. Dudwick and H.G. de Soto, 1330. Madison: University of Wisconsin Press.

Fardon, R. 1990. Localizing strategies: the regionalization of ethnographic accounts. General introduction. In Localizing Strategies: Regional Traditions on Ethnographic Writing (ed.) R. Fardon, 1-35. Edinburgh: Scottish Academic Press, and Washington: Smithsonian Institution Press.

Hann, C.M., C. Humphrey and K. Verdery. 2002. Introduction: postsocialism as a topic of anthropological investigation. Farewell to the socialist 'other'. In PostSocialism; Ideals, Ideologies and Practices in Eurasia (ed.) C.M. Hann, 1-29. London and New York: Routledge.

Harvey, D. 1994. The Condition of Postmodernity; Anthropology Into the Origins of Cultural Change. London: Blackwell. 
Hassiotis, I.K. (ed.). 1997. I Ellines tis Rossias kai tis Sovietikis Enossis [The Greeks of Russia and the Soviet Union]. Thessaloniki: University Studio Press.

Heidegger, M. 2003. Poetically, man dwells... In Heidegger Martin: Philosophical and Political Writing (ed.) M. Stassen, 265-279. New York and London: Continuum.

Herzfeld, M. 1987. Anthropology Through the Looking-glass: Critical Ethnography in the Margins of Europe. Cambridge: Cambridge University Press.

- 2000. Afterword: intimations from an uncertain place. In Fieldwork Dilemmas; Anthropologists in Postsocialist States (eds) N. Dudwick and H.G. de Soto, 219235. Madison: University of Wisconsin Press.

Lefebvre, H. 1991. The Production of Space. Oxford: Blackwell.

Saakashvili, M. 2004. Interview. 24-saati No 34, 11.02.2004, Section A.

Silverman, C. 2000. Researcher, advocate, friend: an American fieldworker among Balkan Roma. In Fieldwork Dilemmas; Anthropologists in Postsocialist States (eds) N. Dudwick and H.G. de Soto, 195-217. Madison: University of Wisconsin Press.

Verdery, K. 1996 What Was Socialism and What Comes Next? Princeton: Princeton University Press.

Wallace, C. 1999. Crossing borders: mobility of goods, capital and people in the Central European region. In Global Futures, Migration, Environment and Globalization (eds) A. Brah, M.J. Hickman, et al, 185-210. London: Routledge.

Wolfe, T.C. 2000. Cultures and communities in the anthropology of Eastern Europe and the former Soviet Union. Annual Review of Anthropology 29, 195-216.

\begin{abstract}
About the author
Eleni Sideri has just completed her $\mathrm{PhD}$ entitled 'The Greeks of the former Soviet Republic of Georgia: memories and practices of diaspora' at SOAS. She studied French Literature and Linguistics at the Aristotle University of Thessaloniki (Greece) and did her postgraduate studies in Social Anthropology and Near and Middle Eastern Studies at SOAS. Her main interests include diasporas, history and issues of gender, cosmopolitanism and globalisation. She can be contacted at elsideri@hotmail.com
\end{abstract}

